\title{
Incidence of Non-Neutropenic Infection (NNI) in Patients with Follicular Lymphoma and Small Lymphocytic Lymphoma:
} The Effects of Rituximab Therapy

\author{
Rezwan ISLAM ${ }^{1}$, Mahbubur RAHMAN ${ }^{2}$, M. Anwarul Huq MIAN ${ }^{3}$, Hilmi EGE ${ }^{1}$, Douglas REDING ${ }^{4}$, \\ Md Abdus SHAKOOR ${ }^{5}$, Hong LIANG ${ }^{6}$, Richard MERCIER $^{4}$
}

\footnotetext{
${ }^{1}$ Marshfield Clinic, Department of Hematology and Oncology, Weston Center, Weston, Wisconsin, U.S.A.

${ }^{2}$ University of Texas Medical Branch, Department of Obstetrics and Gynecology, Galveston, Texas, U.S.A.

${ }^{3}$ Joseph M. Still Research Foundation at Doctors Hospital, Augusta, Georgia, U.S.A.

${ }^{4}$ Oncology, Marshfield Clinic, Department of Hematology, Marshfield Center, Marshfield, Wisconsin, U.S.A.

${ }^{5}$ Bangabandhu Sheikh Mujib Medical University, Department of Physical Medicine \& Rehabilitation, Dhaka, BANGLADESH
}

${ }^{6}$ Marshfield Clinic Research Foundation, Department of Biostatistics and Bioinformatics, Marshfield, Wisconsin, U.S.A.

\begin{abstract}
Rituximab is an anti-CD20 monoclonal antibody that has demonstrated efficacy in patients with indolent and aggressive forms of non-Hodgkin's lymphoma and has become part of the standard therapy for patients with B-cell malignancies. The study was designed to examine if rituximab increases the risk to develop non-neutropenic infection (NNI). Medical records of 202 patients diagnosed as follicular lymphoma or small lymphocytic lymphoma were reviewed. Negative binomial regression was used to estimate relative risk (RR) of NNI. Rituximab ( $n=41)$ and non-rituximab $(n=161)$ groups had a total of 31.636 and 195.691 reviewed patient days, and recorded a total of 67 and 154 infections, respectively. Negative binomial regression analysis revealed significant effects for the treatment (rituximab vs. non-rituximab) and age $(p<0.01)$. The RRs of viral and bacterial NNI for rituximab group compared to nonrituximab group were 3.33 and 2.60, respectively; while the RRs for one year increment of age were 1.03 and 1.04, respectively. The time-to-first viral and bacterial NNI for rituximab group were significantly faster than non-rituximab group. Rituximab may increase the risk of NNI in patients with follicular lymphoma or small lymphocytic lymphoma.
\end{abstract}

Keywords: Rituximab, Follicular lymphoma, Small lymphocytic lymphoma, Incidence, Infection 
Foliküler lenfomalı ve Küçük Lenfositik lenfomalı Hastalarda Nötropenik Olmayan Enfeksiyon İnsidansı: Rituximab Tedavisinin Etkisi

Rituximab bir anti-CD20 antikorudur ve indolant ve agresif Hodgkin dışı lenfomada etkinliği gösterilmiş ve B-hücreli lenfomaların standart tedavisi haline gelmiştir. Bu çalışma rituximab'ın nötropenik olmayan enfeksiyonları artııp artırmadığını test etmek üzere planlandı. Foliküler lenfoma veya küçük lenfoısitik lenfolmalı 202 hastanın hastane kayıtları incelendi. Risk tahmini için negatif binomial regresyon analizi kullanıldı. Rituximab $(n=41)$ ve rituximabsız $(n=161)$ gruplarda total olarak 31.636 ve 195.691 hasta/gün değerlendirildi ve toplam 67'ye karşın 154 enfeksiyon saptandı. Negatif binomial regresyon analizde tedavi ve yaş önemli faktörler olarak bulundular $(p<0.01)$. Viral ve bakterial non-nötropenik enfeksiyonların relatif riskleri rituximab grubunda rituximab almayan gruba göre sırasıyla 3.33 ve 2.60 olarak saptandı. her bir yıl yaş artışında relatif riski sırasıyla 1.3 ve 1.04 olarak saptandı. Illk viral ve bakterial non-nötropenik enfeksiyon gelişmesi, rituximab grubunda rituximabsız gruba göre belirgin olarak daha hızlı idi. Sonuç olarak, rituximab, foliküler veya küçük lenfositik lenfomalı hastalarda non-nötropenik enfeksiyon riskini artırmaktadır.

Anahtar Kelimeler: Rituximab, Foliküler lenfoma, Küçük lenfostik lenfoma, İnsidans, Enfeksiyon

\section{INTRODUCTION}

Rituximab is an anti-CD20 monoclonal antibody that has demonstrated efficacy in patients with indolent and aggressive forms of non-Hodgkin's lymphoma and has become part of the standard therapy for patients with B-cell malignancies. Given that it targets all CD20+ B lymphocytes, it would be expected that rituximab reduces circulating antibody levels, causes humoral-mediated immunosuppression, and increases risk for infection. Initial clinical trials showed that rituximab therapy was well-tolerated and was not associated with increased risk of infection. ${ }^{1,2}$ However, more recent studies have suggested that the risk of infection may have been underestimated in earlier studies. ${ }^{3-8}$

Although the risk of serious infections is thought to be considerably lower with rituximab monotherapy than with conventional chemotherapy, ${ }^{9}$ the true incidence of rituximab-related infections has not been determined. Non-randomized trial data have shown an overall incidence rate of $31 \%$, and $2-4 \%$ incidence of severe infections ${ }^{9}$ associated with rituximab therapy. It is known that rituximab can cause prolonged B-cell deficiency and decreased immunoglobulin levels. ${ }^{10-12}$ Taken together, these observations appear to implicate an association between rituximab therapy and increased risk of non-neutropenic infection (NNI). A retrospective study to explore this association was undertaken to investigate whether the incidence of non-neutropenic bacterial and viral infections is higher in patients with follicular lymphoma or small lymphocytic lymphoma treated with rituximab compared to patients who have received no treatment.

\section{PATIENTS AND METHODS}

Study Design: Retrospective chart review was applied to individuals $(n=202)$ with a diagnosis of follicular lymphoma (FL) or small lymphocytic lymphoma (SLL) during the observational time frame from 1/1/1999 to 4/30/2008 was undertaken to determine the incidence of rates of non-neutropenic infections of patients grouped into two categories defined by treatment approach during the time frame of up to five-years following the index treatment. Patients who had any FL or SLL-related surgery were excluded from the study. Patients in subgroup A $(n=41)$ were treated with rituximab monotherapy with no concomitant treatment with other chemotherapeutic agents for a period of $>3$ months. Infection rates among these patients were compared to those patients in subgroup B $(n=161)$ who received no treatment with any chemotherapeutic agents.

Data collection: Data collected included demographic data (age, gender); smoking status, infection classification (viral, bacterial or fungal), infection recurrence, 60 month average for white cell counts, neutrophil count, lymphocyte count, lymphocyte percent of total leukocyte count and antibody levels for IgG, IgM and IgA. Effect on the following concomitant conditions or treatments were also asses- 


\begin{tabular}{|c|c|c|c|}
\hline & $\begin{array}{l}\text { Rituximab } \\
(\mathrm{N}=41, \mathrm{D}=31636)\end{array}$ & $\begin{array}{l}\text { Non-treatment } \\
(\mathrm{N}=161, \mathrm{D}=195691)\end{array}$ & P-value \\
\hline Mean age $\pm S D(y r)$ & $69.2 \pm 13.3$ & $69.6 \pm 12.0$ & 0.845 \\
\hline Male (\%) & 18 (43.9) & $91(56.5)$ & 0.148 \\
\hline Smoking (\%) & & & 0.463 \\
\hline Current smoker & $3(7.3)$ & $24(14.9)$ & \\
\hline Past smoker & $18(43.9)$ & $57(35.4)$ & \\
\hline Never smoker & $17(41.5)$ & $72(44.7)$ & \\
\hline No documented & $3(7.3)$ & $8(5.0)$ & \\
\hline Deceased & 7 & 40 & 0.507 \\
\hline Hospitalization (rate) & $41(1.30)$ & $185(0.95)$ & 0.197 \\
\hline Bacterial infection (rate) & $49(1.55)$ & $120(0.61)$ & 0.002 \\
\hline Fungal infection (rate) & $2(0.06)$ & $2(0.01)$ & 0.096 \\
\hline Viral infection (rate) & $16(0.51)$ & $32(0.16)$ & $<0.001$ \\
\hline Common viral inf. (rate) & $14(0.44)$ & $23(0.12)$ & $<0.001$ \\
\hline Viral reactivation inf. (rate) & $2(0.06)$ & $9(0.05)$ & 0.658 \\
\hline
\end{tabular}

sed: hypertension, diabetes mellitus, chronic obstructive airway disease (COPD), rheumatoid arthritis (RA), prior cancer diagnosis, asthma and concurrent steroid use. Effect of seasonality of documented infection was also assessed

Analysis: The total number of infections in each treatment-defined group was determined and infection rate was calculated. Negative binomial regression analysis was applied to explore effects of treatment on infection rate and relative risk was calculated and adjusted for effects of age, concomitant conditions including hypertension, diabetes mellitus, COPD, RA, prior cancer diagnosis, asthma and concurrent steroid use. Survival analysis using Kaplan Meier estimate with Log rank test was also undertaken for time to first infection. Effect of treatment on first and recurrent viral infection was also examined using negative binomial regression analysis and survival analysis using Kaplan Meier estimate with Log rank test for time to first infection and recurrence. Chi squared analysis was applied to detect any existing relationship between inci- dent infection and season. All analyses were performed using SAS v9.2, and P-values $<0.05$ were considered to be statistically significant.

\section{RESULTS}

Rituximab treatment $(n=41)$ and non-treatment group $(n=161)$ had a total of 31636 and 195691 reviewed patient days, and resulted in detection of a total of 67 and 154 infections, respectively. Rates of infection and classification of causative agent among patients treated with rituximab and untreated patients are shown in Table 1.

Viral Infection: For viral infection, negative binomial regression analysis revealed significant effects for treatment $\mathrm{p}$-value $<0.001$ and age $(\mathrm{P}$ - value $=$ 0.008 ); the NB model fits the data well with Goodness-of-fit (deviance) Chi-square $=119.307, \mathrm{DF}$ $=199$, and P-value $=1.000$. The relative risk $(\mathrm{RR})$ of viral infection in the presence of rituximab treatment was 3.33 (95\% Confidence Interval (CI): 1.91-5.81), and RR of viral infection with incre- 


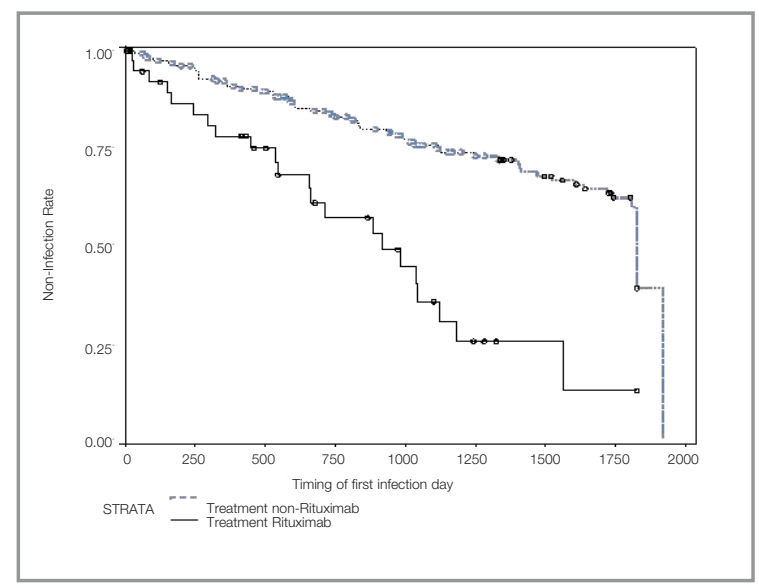

Figure 1. Time to first common viral infection curves for rituximab and non-treatment groups

asing age was 1.03 (95\% CI: 1.01-1.05). It was estimated that an increase in age by one year carried with it an increased risk of infection by $3 \%$.

The study looked at incidence of 'common viral infection' (defined as viruses associated with common cold and upper respiratory symptoms such as adenovirus or rhinovirus) and reactivation of chronic viral infections such as Herpes zoster and Hepatitis $\mathrm{C}$ viruses. Survival analysis in the two groups revealed that the time to first infection in rituximab treatment group was significantly faster, median time-to-first infection was 917 days (95\% CI: 5461184) compared to the group with no treatment, median 1827 days (95\% CI: 1737-1827, P- value < $0.001)$

Frequency of reactivation infection was further examined (Table 1). However rates of reactivation infection could not be statistically analyzed due to low incidence in the available sample. Fungal infection rates were similarly too low to permit statistical analysis. Thus, survival analysis for viral infection largely represented common infection rates.

If only common viral infection was examined to the exclusion of reactivation infection, negative binomial regression analysis revealed significant effects for the treatment with rituximab and increasing age, $(\mathrm{P}<0.001$ and $\mathrm{P}=0.006$, respectively $)$; the NB model fits the data well with Goodness-of-fit (deviance) Chi-square $=98.730, \mathrm{DF}=199$, and P-value $=$ 1.000 The RR of common viral infection for rituximab treatment group was 4.20 (95\% CI: 2.36-7.49),

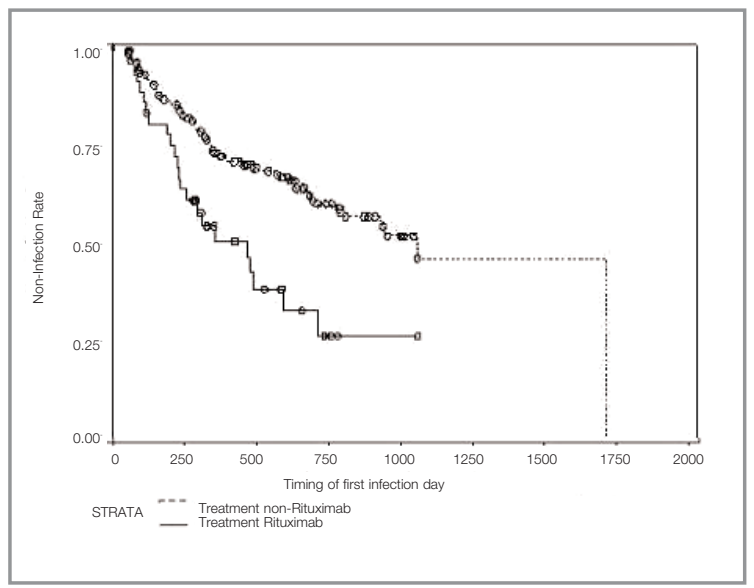

Figure 2. Time-to-first bacterial infection curves for rituximab treatment and no-treatment

and RR of infection for age was $1.03(95 \% \mathrm{CI}$ : 1.01-1.06). Survival analysis revealed that the timeto-first common viral infection for Rituximab treatment group was significantly faster, median timeto-first infection was 917 days (95\% CI: 655-1123), vs. no treatment group, median 1827 days, (95\% CI: NA, P value $<0.001$ ) (Figure 1)

Bacterial Infection: Rates of bacterial infection in the rituximab treatment group and non treated group were shown in Table 1. For bacterial infection, negative binomial regression analysis revealed significant effects for the rituximab treatment and increasing age, $(\mathrm{P}=0.002$ and $\mathrm{P}=0.003$, respectively), the NB model fits the data well with Goodness-offit (deviance) Chi-square $=168.211, \mathrm{DF}=199$, and $\mathrm{P}$-value $=0.945$. The RR of bacterial infection for rituximab was 2.60 (95\%CI: 1.41-4.79), and RR of bacterial infection with increasing age was 1.04 (95\% CI: 1.01-1.06). Survival analysis revealed that the time-to-first bacterial infection for rituximab treatment group was significantly faster, median time-to-first infection was 756 days $(95 \% \mathrm{CI}$ : 327-1199), vs. Non-treatment group, median 1827 days (95\% CI: $1343-3018, \mathrm{P}-$ value $=0.001)$. (Figure 2)

Only COPD emerged as a significant factor following application of negative binomial regression analysis during analysis of co morbidities and effect on risk relative to bacterial infection rates only, $\mathrm{RR}=2.76$, $\mathrm{p}$-value $=0.027$. 
Survival analysis: Survival analysis revealed that the treatment (rituximab vs. Non-treatment) was not a significant risk factor for survival, the relative risk $(\mathrm{RR})$ of rituximab was $0.76, \mathrm{P}$-value $=0.507$ based on data shown in Table 1. Age was the only risk factor which emerged relative to the survival analysis, with an RR of 1.103, $(\mathrm{p}<0.001)$ associated with increasing age.

Comparison of hospitalization rate: Rituximab treatment and non-treatment group underwent review of a total of 31636 and 195691 reviewed patient days, respectively, and a total of 41 and 185 hospitalizations, respectively were captured for a hospitalization rate of 1.3 and 0.95 , respectively per thousand patient days. (Table 1) Negative Binomial regression analysis revealed that age was also a significant factor for hospitalization rate, $\mathrm{P}$-value $<$ 0.001 ; while the treatment (rituximab vs. Non-treatment) was not a significant risk factor, P-value= 0.197 . Wilcoxon rank sum test did not demonstrate significant difference in the length of hospital stay between rituximab treatment and non-treatment groups, (rituxamab treatment group median $=3$ days vs. non-treatment group median $=4$ days, $\mathrm{P}-$ value $=$ $0.525)$.

Seasonal effect: Finally no evidence of a relationship in general infection, bacterial or viral infection was noted in either the rituximab treatment group or untreated group relative to season when infections occurred. (data not shown)

\section{DISCUSSION}

Follicular lymphoma and small lymphocytic lymphoma are two types of non-Hodgkin's lymphoma. Patients with these forms of cancers have traditionally been treated with a variety of chemotherapeutic agents and combinations of these agents. Relapse is common following treatment with standard therapies; thus, alternative therapeutic approaches have been the focus of much investigation.

Rituximab has proven to be an effective adjunct to various chemotherapy regimens for the treatment of non-Hodgkin's lymphoma, alone or in combination with other regimens. ${ }^{13-16}$ Rituximab is a chimeric antibody which specifically recognizes and binds to the CD20 antigen uniquely expressed on the surface of B cells, specifically targeting these for immune-mediated elimination.

Since its approval by the FDA in 1997 for the treatment of relapsed or refractory non-Hodgkin's lymphoma, rituximab alone or in combination with chemotherapeutic regimens has become standard therapy for patients with B-cell lymphomas. It has also been indicated for the treatment of autoimmune diseases. Studies have shown that rituximab improves outcomes and response rates in patients with non-Hodgkin's lymphoma. ${ }^{13-16}$ However, rituximab also depletes peripheral B cells, decreases immunoglobulin levels, and may increase patients' susceptibility to NNIs. ${ }^{10-12}$

If unrecognized or untreated, NNIs can cause increased morbidity and mortality and decreased quality of life for cancer patients. However, NNIs can be effectively treated with intravenous immunoglobulins and antibiotics if recognized and/or predicted. Little is known regarding the incidence of NNI's in patients with non-Hodgkins lymphoma and the association of NNIs incidence rates with rituximab therapy.

Little information currently exists regarding immune status in patients treated with rituximab. There are a number of regimens currently being administered which vary in frequency and duration. Peripheral B cell counts decline below normal following the first dose of rituximab. B cell repletion typically begins within 6 months of treatment and returns to normal levels between 9 and 12 months after completion of therapy.$^{17}$ Prolonged B cell depletion leads to variable suppression of serum immunoglobulins and, therefore, may increase the risk of NNIs. More complete information on incidence rates of infection in patients receiving rituximab monotherapy is needed in order to optimize treatment guidelines in these patients.

At present, rituximab is used with several different therapeutic regimens for the treatment of NHL. Rituximab is administered as monotherapy for previously untreated patients and for those with relapsed NHL who have responded to at least one prior course of rituximab. It is also administered concomitantly with different regimens of chemotherapy, including rituximab + fludarabine, rituximab + CHOP (cyclophosphamide, doxorubicin, vincristi- 
ne, and prednisone), rituximab + FND (fludarabine, mitoxantrone, and dexamethasone), and rituximab + MCP (mitoxantrone, chlorambucil, and prednisone). Lastly, rituximab is administered in conjunction with stem cell transplantation both before stem cell collection and after transplantation.

The standard dose of rituximab monotherapy is 375 $\mathrm{mg} / \mathrm{m} 2$ given once a week for a total of four applications (18). If combined with chemotherapy, the standard dose is $375 \mathrm{mg} / \mathrm{m}^{2}$ for 8 cycles (21 days/cycle), administered on day 1 of each chemotherapy cycle. Rituximab maintenance therapy is given at $375 \mathrm{mg} / \mathrm{m}^{2}$ once every 3 months until disease progression or for a maximum period of two years. ${ }^{19}$ However, modifications to these schedules have been investigated, and alternative approaches included higher doses or an increase in the number of applications given.

The rationale for focusing the study on two types of non-Hodgkin's lymphoma, namely, follicular lymphoma and small lymphocytic lymphoma, was threefold. First, these lymphomas affect Blymphocytes, and B lymphocytes are also the therapeutic target of rituximab. Second, patients with these lymphomas were least likely to be impacted by other immunosuppressive treatments which may otherwise confound a study of NNI incidence in this patient population. Further, diagnosed patients under observation but not treated offer the best control for patients who had survived treatment and were on maintenance therapy relative to disease severity and underlying immune status.

Data from this retrospective study indicated that patients receiving rituximab treatment experienced sooner viral and bacterial infection rates than patients receiving no treatment and an increased frequency of infection. Rituximab treatment was associated with a RR for both viral and bacterial infection. For viral infection, treatment (rituximab treatment vs. no treatment, $\mathrm{P}<0.001)$ and increased age $(\mathrm{P}=0.008)$ were significant factors. For bacterial infection, treatment (rituximab treatment vs. no treatment $\mathrm{P}=0.002)$, increased age $(\mathrm{P}=0.003)$, and presence of underlying COPD $(\mathrm{P}=0.027)$ were significant factors. For viral and bacterial infection, the infection rates (per thousand patient days) were $0.51(16 / 31636)$ and $1.55(49 / 31636)$ for the rituximab treatment group, $0.16(32 / 195691)$ and 0.61
(120/195691) for the non treatmen $t$ group, respectively. The RR of viral and bacterial infection with rituximab treatment were 3.33 (95\%CI: 1.91-5.81, $\mathrm{P}<0.001)$ and 2.60 (95\% CI: 1.41-4.79, $\mathrm{P}=0.002$ ), respectively. Furthermore, for common viral infection associated with adeno and rhino viral infection and reactivation of a chronic viral infection, infection rates were $0.44(14 / 31636)$ and $0.06(2 / 31636)$ for the rituximab treatment group, and 0.12 $(23 / 195691)$ and $0.05(9 / 195691)$ for the non treatment group, respectively. The RR for common viral infection alone with rituximab treatment was 4.20 (95\%CI: $2.36-7.49, \mathrm{P}<0.001$ ). Thus, for viral infection, higher RR was only associated with common viral infection. No significant differences related to treatment emerged relative to seasonal effect, length of stay or survival.

Certain study limitations need to be acknowledged. Because of its retrospective design, the study was limited to data available in the medical records regarding the history of the infections that were detected. It is possible that some patients may have had additional infections during the observational time frame that were not captured in the medical record, so that infection rates were limited to those associated with a clinic visit. Thus the true infection rate may actually be higher than the rate detected, but this would require a prospective study design in which monitoring of patients for incidence of any infections could be more efficiently achieved. Finally, the size of the rituximab treatment group was relatively modest. To validate the data presented herein, ideally a prospectively designed adequately powered study would be ideal. Additionally, because of the retrospective nature of the study, information on immune status including periodic evaluation of immunoglobulin levels was had only been determined on a relatively small subset of the population and among those patients, data collection for some of the time points was not available, making analysis of the these data problematic. Ideally, in a prospective study design monitoring of immune status would be included in the study design. However, data presented herein should increase clinician awareness of the potential for greater susceptibility to viral and bacterial infection that patients receiving rituximab treatment may have. 


\section{REFERENCES}

1. McLaughlin P, Grillo-López AJ, Link BK, et al. Rituximab chimeric anti-CD20 monoclonal antibody therapy for relapsed indolent lymphoma: half of patients respond to a four-dose treatment program. J Clin Oncol 16: 2825-2833, 1998.

2. Davis TA, Grillo-López AJ, White CA, et al. Rituximab anti-CD20 monoclonal antibody therapy in non-Hodgkin's lymphoma: safety and efficacy of re-treatment. J Clin Oncol 18: 3135-3143, 2000.

3. Nishio M, Fujimoto K, Yamamoto S, et al. Hypogammaglobulinemia with a selective delayed recovery in memory B cells and an impaired isotype expression after rituximab administration as an adjuvant to autologous stem cell transplantation for non-Hodgkin lymphoma. Eur J Haematol 77: 226-232, 2006.

4. Lim SH, Zhang $\mathrm{Y}$, Wang Z, et al. Maintenance rituximab after autologous stem cell transplant for high-risk B-cell lymphoma induces prolonged and severe hypogammaglobulinemia. Bone Marrow Transplant 35: 207-208, 2005.

5. Goldberg SL, Pecora AL, Alter RS, et al. Unusual viral infections (progressive multifocal leukoencephalopathy and cytomegalovirus disease) after high-dose chemotherapy with autologous blood stem cell rescue and peritransplantation rituximab. Blood 99:1486-1488, 2002.

6. Lin PC, Hsiao LT, Poh SB, et al. Higher fungal infection rate in elderly patients (more than 80 years old) suffering from diffuse large B cell lymphoma and treated with rituximab plus CHOP. Ann Hematol 86: 95-100, 2007.

7. Iyer A, Mathur R, Deepak BV, et al. Fatal adenoviral hepatitis after rituximab therapy. Arch Pathol Lab Med 130: 1557-1560, 2006.

8. Wadhwa PD, Morrison VA. Infectious complications of chronic lymphocytic leukemia. Semin Oncol 33: 240249, 2006.

9. Plosker GL, Figgit DP. Rituximab: a review of its use in non-Hodgkin's lymphoma and chronic lymphocytic leukaemia. Drugs 63: 803-843, 2003.

10. Horwitz SM, Negrin RS, Blume KG, et al. Rituximab as adjuvant to high-dose therapy and autologous hematopoietic cell transplantation for aggressive non-Hodgkin lymphoma. Blood 103: 777-783, 2004.

11. Maloney DG, Grillo-Lopez AJ, White CA, et al. IDECC2B8 (Rituximab) Anti-CD20 Monoclonal Antibody Therapy in Patients with Relapsed Low-Grade NonHodgkin's Lymphoma. Blood 90: 2186-2195, 1997.

12. Shortt J, Spencer A. Adjuvant rituximab causes prolonged hypogammaglobulinaemia following autologous stem cell transplant for non-Hodgkin's lymphoma. Bone Marrow Transplant 38: 433-436, 2006.
13. Hiddemann W, Kneba M, Dreyling M, et al. Frontline therapy with rituximab added to the combination of cyclophosphamide, doxorubicin, vincristine, and prednisone (CHOP) significantly improves the outcome for patients with advanced-stage follicular lymphoma compared with therapy with $\mathrm{CHOP}$ alone: results of a prospective randomized study of the German LowGrade Lymphoma Study Group. Blood 106: 37253732, 2005.

14. Czuczman MS, Koryzna A, Mohr A, et al. Rituximab in combination with fludarabine chemotherapy in lowgrade or follicular lymphoma. J Clin Oncol 23: 694704, 2005.

15. van Oers $\mathrm{MH}$, Klasa R, Marcus RE, et al. Rituximab maintenance improves clinical outcome of relap$\mathrm{sed} /$ resistant follicular non-Hodgkin lymphoma in patients both with and without rituximab during induction: results of a prospective randomized phase 3 intergroup trial. Blood 108: 3295-301, 2006.

16. Forstpointner $R$, Dreyling $M$, Repp $R$, et al. The addition of rituximab to a combination of fludarabine, cyclophosphamide, mitoxantrone (FCM) significantly increases the response rate and prolongs survival as compared with FCM alone in patients with relapsed and refractory follicular and mantle cell lymphomas: results of a prospective randomized study of the German Low-Grade Lymphoma Study Group. Blood 104: 3064-3071, 2004.

17. Cvetkovi_RS, Perry CM. Rituximab: A review of its use in non-Hodgkin's lymphoma and chronic lymphocytic leukemia. BioDrugs 66: 791-820, 2006.

18. Boye J, Elter T, Engert A. An overview of the current clinical use of the anit-CD20 monoclonal antibody rituximab. Ann Oncol 14: 520-535, 2003.

19. Roche Registration Limited. MabThera 100mg: summary of product characteristics [Roche Website] Available at: http://www.rocheuk.com/portal/eipf/ united_kingdom/ prescription_products/. Accessed February 12, 2007.

\section{Correspondence \\ Rezwan ISLAM, MD \\ Marshfield Clinic Weston Center \\ 3501 Cranberry Boulevard, Weston, WI 54476}

Tel: 715-393-1400, Fax: 715-393-1399

Email: islam.rezwan@marshfieldclinic.org 